\title{
EFEKTIVITAS SISTEM INFORMASI DAN KOMPUTERISASI HAJI TERPADU (SISKOHAT) DALAM PENYELENGGARAAN IBADAH HAJI
}

\author{
Zahrotun Munawaroh, M. Mudhofi, Dedy Susanto \\ MTs Darul Falah Pati
}

Email: el.zahra294@gmail.com; hm.mudhofi@yahoo.co.id; dedyssosi@gmail.com

\begin{abstract}
The purpose of this research consist of: 1). How the effectivity of implementation hajj in regional office of the ministry of religion in Jawa Tengah Province, 2), What the supporting and obstacle factors of SISKOHAT implementastion. This research is qualitative describtive research. The method of collecting data use three method, there are observation, interview, and documentation. The outcame from the research shows that Siskohat implementation is really effective to increase services performance of hajj implementation in regional office of the ministry of religion in Jawa Tengah Province. Integrated Siskohat with 17 BPS BPIH with host in center of ministry of religion. The Siskohat process include registration and saving database of worshipers and officers, paspor and visa process, publish the administration document (DAPIH), online payment of BPIH by BPS BPIH, BPIH acountance system, pramanifets kolter making, flight monitoring, healthiness monitoring, and monitoring of hajj operational in Indonesia and Arab Saudi.

Penelitian ini mengkaji; 1) Bagaimana Efektivitas dalam penyelenggaraan ibadah haji di Kantor Wilayah Kementerian Agama Provinsi Jawa Tengah, 2) Apa yang menjadi faktor pendukung dan penghambat penerapan SISKOHAT. Jenis penelitian ini adalah penelitian kualitatif deskripstif. Proses pencariaan data melalui tiga cara yaitu observasi, wawancara dan dokumentasi. Kesimpulan yang diperoleh, bahwa penerapan SISKOHAT sangat efektif dalam meningkatkan kinerja pelayanan penyelenggaraan ibadah haji di Kanwil Kemenag Provinsi Jawa Tengah. SISKOHAT terintegrasi dengan 17 BPS BPIH dan Kantor Kementerian Agama di seluruh Indonesia dengan Host pusat di Kementerian Agama Pusat. Pelayanan SISKOHAT mencakup pendaftaran dan penyimpanan database jamaah dan petugas haji, pemrosesan dokumen paspor dan pemvisaan, penerbitan Dokumen Administrasi Perjalanan Ibadah Haji (DAPIH), pembayaran BPIH oleh BPS BPIH secara online, pelaksanaan sistem akuntansi BPIH, penyususnan pramanifest kloter, monitoring penerbangan, pemantauan kesehatan haji, serta pemantauan operasional haji di Tanah Air dan di Arab Saudi.
\end{abstract}

Keywords: Effectivity, information and computerization system, implementation of hajj 


\section{A. Pendahuluan}

Haji merupakan salah satu dari kelima aspek rukun Islam, yang mana tidak sempurna Islam seseorang yang mampu menunaikan haji sampai ia berhaji. ${ }^{1}$ Haji pada hakekatnya merupakan aktifitas suci yang pelaksanaannya diwajibkan oleh Allah kepada seluruh umat Islam yang telah mencapai istitho'ah (mampu), disebut rangkaian suci karena seluruh rangkaian kegiatannya adalah ibadah.

Ibadah haji merupakan ibadah terfavorit bagi sebagian kalangan masyarakat Indonesia. Sebagai negara dengan penduduk mayoritas muslim, sudah tentu setiap tahunnya ribuan jamaah haji diberangkatkan dari Indonesia untuk melaksanakan ibadah haji di Tanah Suci. Akibatnya peningkatan pendaftaran jamaah haji dari tahun ke tahun begitu pesat. Pada tahun 2015 jumlah pendaftar di Jawa Tengah mencapai angka 458.650 jiwa. ${ }^{2}$ Angka pendaftar yang setiap tahunnya mengalami peningkatan serta adanya pembatasan quota jamaah haji yang berangkat ke Tanah Suci, menyebabkan penumpukan calon jamaah haji yang semakin bertambah panjang. kondisi ini menjadikan daftar tunggu (waiting list) keberangkatan ibadah haji ke Baitullah semakin panjang hingga mencapai 19-20 tahun. Waiting list dari tahun ke tahun yang telah mencapai puluhan tahun tidak mungkin dilakukan dengan cara manual, konvensional, dengan mengandalkan tumpukan berkas ataupun menggunakan sistem komputer yang tidak terhubung oleh jaringan. Hal ini akan memperlambat kinerja lembaga pelayanan bagi publik di lembaga Kementerian Agama.

Pentingnya peranan informasi dan teknologi dalam pengelolaan suatu pelayanan penyelenggaraan ibadah haji merupakan hal yang mutlak dibutuhkan. Faktor pemicunya ialah semakin majunya masyarakat Indonesia karena berbagai faktor seperti pendidikan, demokrasi politik, pembangunan ekonomi serta berbagai macam permasalahan yang bentuk, jenis dan intensitasnya berbeda dari masa-masa sebelumnya. Sehingga Bidang Penyelenggaraan Ibadah Haji di Kantor Wilayah Kementerian Agama Provinsi Jawa Tengah harus mampu memberikan peningkatan dalam hal pelayanan informasi serta pengelolaan sistem pelayanan manual menuju sistem pelayanan pendataan calon jamaah haji secara otomatis. Oleh karena itu, terobosan dibidang teknologi dan informasi, baik dalam arti perangkat kerasnya, perangkat lunaknya dan perangkat otaknya sangat dibutuhkan.

1 Tholal Bin Ahmad Al-'aqil, Petunjuk Bagi Jamaah Haji dan Umroh, (1427H), hlm. 7

${ }^{2}$ Arsip Kantor Wilayah Kementerian Agama Provinsi Jawa Tengah 
Dipihak lain tuntutan masyarakat akan pemenuhan pelayanan haji yang semakin berkualitas menjadi tugas besar pemerintah. Pada akhirnya dampak besar yang sangat dirasakan akibat masih minimnya teknologi pendataan dan pengolahan data dalam penyelenggaraan ibadah haji, yaitu terjadinya peristiwa tragedi kecelakaan di Terowongan Mina yang memakan korban sebanyak 1.426 jiwa, 649 jiwa diantaranya ialah jemaah haji asal Indonesia. ${ }^{3}$ Pemerintah mengalami sulitnya dalam identifikasi pendataan korban, serta sulitnya dalam menginformasikan musibah tersebut kepada keluarga korban karena teknologi informasi yang masih manual, dimana semua proses dalam pelayanan haji baik yang terkait dengan administrasi dan dokumentasi, sampai pada kegiatan pelaksanaan ibadah haji masih menggunakan teknologi informasi yang sederhana dan lambat.

Peningkatan calon jamaah haji dari tahun ke tahun, menuntut Bidang Penyelenggaraan Haji dan Umroh Kantor Wilayah Kementerian Agama Provinsi Jawa Tengah untuk senantiasa melakukan berbagai hal pembenahan, penataan dan perubahan. Bahkan bila perlu reform atau merekonstruksi struktur organisasi, Sumber Daya Manusia, serta Sistem Informasi dan Komputerisasi dalam upaya melakukan pembenahan peningkatan pelayanan bagi publik. Sebagai penyelenggara dan pemberi layanan, Kantor Wilayah Kementerian Agama Provinsi Jawa Tengah memiliki tanggung jawab penuh sebagai penyelenggara dan pemberi pelayanan kepada jamaah haji dengan mengeluarkan berbagai kebijakan yang menyangkut pelayanan ibadah haji mulai dari perumusan dan pelaksanaan, penyusunan norma-norma, standar operasional, prosedur, dan kriteria, bimbingan teknis, monitoring operasional ibadah haji serta evaluasi dalam pelayanan penyelenggaraan ibadah haji.

Upaya untuk meningkatkan pelayanan haji terus dilakukan oleh Bidang Penyelenggaraan Ibadah Haji dan Umroh Kantor Wilayah Kementerian Agama Provinsi Jawa Tengah dengan melakukan evaluasi terhadap hasil pelaksanaan penyelenggaraan haji dari tahun ke tahun yang kemudian ditindak lanjuti dengan penyempurnaan pola pelayanan untuk mengatasi kekurangan-kekurangan yang terjadi.

Pelayanan haji di Indonesia dari tahun ke tahun menunjukkan perubahan yang signifikan, diawali pada tahun 1990-an, dimana pada masa itu kondisi dalam pelayanan informasi dan pengolahan data jamaah haji baik dokumentasi, pengarsipan sampai pada pengurusan keuangan masih dilakukan secara manual sehingga sulit dikontrol secara cepat yang

\footnotetext{
3Tulus, "Refleksi Perjalanan SISKOHAT", Realita Haji, Edisi 02 Mei 2014, hlm. 6
} 
kemudian menjadi permasalahan penting. Pemerintah tidak mampu untuk mengontrol dan mengendalikan secara penuh terhadap pemenuhan kuota, dan keuangan haji. Pada awal tahun 1995 pemerintah bekerja sama dengan Garuda Indonesia dalam meningkatkan pelayanan penyelenggaraan ibadah haji. Pemerintah menggunakan main system milik Garuda sebagai host SISKOHAT yang tersambung dengan 7 BPS BPIH. Pengembangan SISKOHAT secara bertahap dan berkesinambungan di Kementerian Agama Kabupaten/Kota setiap tahunnya mengalami peningkatan, tahun 2010 Kementerian Agama pusat meluncurkan SISKOHAT versi terbarunya yaitu SISKOHAT Gen-1. Sebagai penyempurna dari SISKOHAT Gen-1 Kementerian Agama meluncurkan SISKOHAT Gen-2 pada tahun 2014. ${ }^{4}$ Sistem tersebut mempunyai fungsi yang lebih komplek dalam peningkatan pelayanan penyelenggaraan ibadah haji secara online dan realtime dengan jumlah BPS BPIH yang semakin bertambah.

Perkembangan pembangunan SISKOHAT tidak hanya dirancang untuk melayani pendaftaran haji secara on-line dan real time, lebih jauh lagi mencakup dukungan terhadap seluruh prosesi penyelenggaraan haji mulai dari pendaftaran calon haji, pemrosesan dokumen haji, persiapan keberangkatan (embarkasi), monitoring operasional di Tanah Suci sampai pada proses kepulangan ke Tanah Air (debarkasi).

Suatu langkah tepat yang telah diambil oleh Kementerian Agama dalam upaya meningkatkan pelayanan haji adalah dengan membangun suatu Sistem Informasi dan Komputerisasi Haji Terpadu (SISKOHAT) yang terhubung dengan Kantor Wilayah Kementerian Agama serta Kementerian Agama seluruh Kabupaten Kota di Indonesia. SISKOHAT merupakan suatu sistem pelayanan secara on-line dan real time antara Bank Penyelenggara Penerima Setoran (BPS BPIH) Ibadah Haji, Kantor Wilayah Kementerian Agama di 33 Provinsi dan kabupaten dengan Host Pusat Komputer untuk penyimpanan seluruh database calon Jamaah Haji di Kementerian Agama Pusat yakni di Jakarta Pusat.

Untuk itu telah disiapkan pula infrastruktur pendukung di Kantor Wilayah Kementerian Agama 33 Provinsi, salah satunya di Kantor Wilayah Kementerian Agama Provinsi Jawa Tengah yang mencakup 12 embarkasi serta rencana pembangunan infrastruktur di seluruh Kantor Kementerian Agama dan infrastruktur di Arab Saudi yang akan On-line ke Pusat SISKOHAT di Jakarta, sehingga secara keseluruhan Sistem Informasi dan Komputerisasi Haji Terpadu (SISKOHAT) akan menjadi suatu Sistem

4 Wawancara dengan Kepala Seksi Informasi Haji Kantor Wilayah Kementerian Agama Provinsi Jawa Tengah, 18-6-2015 
Informasi yang terintegrasi dalam satu database untuk mendukung dan meningkatkan pelayanan penyelenggaraan ibadah haji terutama dalam aspek pengelolaan informasi haji.

Berdasarkan uraian latar belakang masalah tersebut, penulis tertarik untuk menganalisis penerapan sistem informasi dan komputerisasi haji terpadu (SISKOHAT) yang ada di Kantor Wilayah Kementerian Agama Provinsi Jawa Tengah. Sehingga penulis mengambil judul penelitian "Efektivitas Sistem Informasi dan Komputerisasi Haji Terpadu (SISKOHAT) dalam Penyelenggaraan Ibadah Haji di Kantor Wilayah Kementerian Agama Provinsi Jawa Tengah Tahun 2015".

\section{B. Kerangka Konseptual}

\section{Konsep}

Efektivitas $^{5}$ merupakan suatu sistem yang berkaitan dengan bagaimana suatu organisasi atau lembaga berhasil mendapatkan dan memanfaatkan sumber daya dalam usaha mewujudkan tujuan operasional. Efektivitas berkaitan dengan terlaksananya semua tugas pokok, tercapainya tujuan, ketepatan waktu dan adanya partisipasi aktif dari semua anggota. Efektivitas sistem informasi dan komputerisasi haji terpadu (SISKOHAT) mencakup bagaimana siskohat berhasil melaksanakan semua tugas pokok yang berkaitan dengan sistem komputer dalam penyelenggaraan ibadah haji, peran siskohat dalam penyelenggaraan ibadah haji, sarana prasarana dalam pemanfaatan sumber daya untuk mewujudkan tujuan lembaga penyelenggaraan ibadah haji dan umroh di Kantor Wilayah Kementerian Agama provinsi Jawa Tengah, serta hasil dari sistem informasi dan komputerisasi haji terpadu yang diterima oleh seluruh calon jamaah haji.

Dalam mencapai efektivitas suatu lembaga, sangat dipengaruhi oleh berbagai faktor yang berbeda-beda tergantung pada sifat dan bidang kegiatan atau usaha suatu lembaga. Adapun faktor yang mempengaruhi tingkat keefektifan Sistem Informasi dan Komputerisasi Haji Terpadu (SISKOHAT) di lembaga penyelenggaraan ibadah haji dan umroh yaitu : 1)

${ }^{5}$ Efektivitas dalam kamus besar bahasa Indonesia berasal dari kata efektif yang diartikan dengan : a) ada efeknya, b) manjur atau mujarab, c) dapat membwa hasil, berhasil guna. (Kamus Besar Bahasa Indonesia, 2005, hlm.284). 
Kecanggihan sistem; 2) Sarana dan fasilitas sistem informasi; 3) Sumber daya manusia atau tenaga ahli; 4) Standar operasional yang berlaku. ${ }^{6}$

Suatu sistem dinilai efektif dan mempunyai nilai aplikatif yang tinggi apabila sistem tersebut dapat memberikan kontribusi nyata dalam memperlancar kegiatan manajemen kelembagaan yang meliputi: 1) Validitas informasi yang diterima; 2) Signifikansi informasi; 3) Kegunaan spesifiknya, termasuk mendukung proses pengambilan keputusan; 4) Hubungan informasi tersebut dengan informasi lain. ${ }^{7}$

Sistem informasi dan komputerisasi merupakan kumpulan dari berbagai perangkat keras dan perangkat lunak komputer serta perangkat manusia yang akan mengolah data menggunakan perangkat keras dan perangkat lunak tersebut. Sistem Informasi merupakan sistem buatan manusia yang terdiri dari komponen-komponen dalam organisasi untuk mencapai suatu tujuan yaitu memberikan informasi bagi pengambil keputusan dan untuk mengendalikan organisasi atau lembaga. ${ }^{8}$

Sistem informasi dalam penyelenggaraan ibadah haji mempertemukan kebutuhan pengolahan transaksi harian dalam mendukung operasi organisasi yang bersifat manajerial dengan kegiatan strategi dari suatu organisasi untuk dapat menyediakan kepada para pihak dengan laporanlaporan yang diperlukan.

Untuk mendukung lancarnya suatu sistem informasi dibutuhkan beberapa komponen yang fungsinya sangat vital di dalam sistem informasi yang meliputi input, proses, output, teknologi, basis data dan kendali. Manfaat dari sistem informasi adalah: pertama, organisasi menggunakan sistem informasi untuk mengolah transaksi-transaksi, mengurangi biaya dan menghasilkan pendapatan sebagai salah satu produk atau pelayanan mereka. Kedua, bank menggunakan sistem informasi untuk mengolah cekcek nasabah dan membuat berbagai laporan rekening koran dan transaksi yang terjadi. Ketiga, organisasi menggunakan sistem informasi untuk mengendalikan kegiatan perencanaan informasi, proses transformasi informasi, serta melaksanakan kegiatan koordinasi. ${ }^{9}$

Adapun elemen-elemen sistem komputerisasi yang terkait untuk menjalankan suatu aktifitas dengan menggunakan komputerterdiri dari

\footnotetext{
6Wawancara dengan Kepala Seksi Informasi Haji Kantor Wilayah Kementerian Agama Provinsi Jawa Tengah, 18-6-2015 hlm.18

${ }^{7}$ Sondang P. Siagian, Sistem Informasi Manajemen, (Jakarta: Bumi Aksara, 2002),

${ }^{8}$ Andri Kristanto, Perancangan Sistem Informasi dan Aplikasinya, (Yogyakarta: Gava Media, 2007), hlm.13

${ }^{9}$ Andri Kristanto, Perancangan Sistem Informasi dan Aplikasinya, (Yogyakarta: Gava Media, 2007), hlm.15
} 
perangkat keras (hardware), perangkat lunak (software), set instruksi (instruction set), dan pengguna (brainware). Elemen tersebut saling terlibat dalam suatu sistem komputer yang terintegrasi dengan berbagai sistem penunjang untuk peningkatan pelayanan penyelenggaraan ibadah haji secara menyeluruh. Sistem komputerisasi sangat penting sebagai penunjang pengambilan keputusan serta keakuratan informasi yang dikeluarkan, karna dalam perkembangannya sistem komputerisasi merupakan manajemen yang berbasis komputer yang berfokus pada data, pengolahan informasi, serta fokus pada pendukung keputusan. Selain itu Sistem Informasi dan Komputerisasi Haji Terpadu (SISKOHAT)sebagai sistem interaksi dua arah dalam pelayanan publik dan lembaga terkaityang memberikan keterbukaan informasi secara cepat, tepat dan akurat kepada masyarakat khususnya calon jamaah haji yang sudah terdaftar.

Dalam Undang-Undang Nomor 13 Tahun 2008 tentang penyelenggaraan haji menyatakan bahwa Penyelenggaraan ibadah haji adalah rangkaian kegiatan yang meliputi pembinaan, pelayanan, dan perlindungan pelaksanaan ibadah haji. Penyelenggaraan ibadah haji bertujuan untuk memberikan pembinaan, pelayanan, dan perlindungan yang sebaik-baiknya melalui sistem dan manajemen penyelenggaraan yang baik agar pelaksanaan ibadah haji dapat berjalan dengan aman, tertib, lancar dan nyaman sesuai dengan tuntunan agama serta jamaah haji dapat melaksanakan ibadah haji secara mandiri dan memperoleh predikat haji mabrur.

Peningkatan pembinaan, pelayanan, dan perlindungan terhadap jama'ah haji terus diupayakan melalui penyempurnaan sistem dan manajemen penyelenggaraan ibadah haji. Penyempurnaan sistem informasi dan komputerisasi haji terpadu (SISKOHAT) merupakan salah satu upaya untuk mengoptimalkan pelayanan untuk para calon jama'ah haji. Sistem inilah yang mengintegrasikan elemen-elemen terpenting penyelenggaraan haji, yakni pendaftaran haji, dokumen haji, dan keuangan haji. ${ }^{10}$ Dengan adanya peningkatan penyelenggaraan ibadah haji dibidang teknologi informasi diharapkan memudahkan calon jama'ah dalam memperoleh pelayanan dan kecepatan informasi sehingga calon jama'ah haji lebih siap dan mandiri dalam menunaikan ibadah haji sesuai dengan tuntunan agama.

10Kementerian Agama, Realita Haji, (Jakarta: Kementerian Agama, 2014), hlm.17 


\section{Kajian pustaka}

Kajian pustaka digunakan untuk memperkaya data penelitian, dan menghindari adanya duplikasi hasil penelitian yang sudah dilakukan sebelumnya, maka penulis akan mengkaji hasil-hasil penelitian terdahulu yang ada relevansinya dengan penelitian ini, di antaranya adalah sebagai berikut:

Pertama, penelitian yang disusun oleh Abdul Latif (Tahun 2010) yang berjudul: Analisis Keberhasilan Siskohat Kantor Wilayah Kementerian Agama Provinsi DIY. Penelitian ini merupakan penelitian kualitatif. Dalam pengumpulan data, Abdul Latif menggunakan metode observasi, wawancara, dan dokumentasi. Data yang terkumpul kemudian diolah dan dianalisis. Analisis data menggunakan analisis deskriptif, yaitu menyajikan data dengan cara menganalisa keberhasilan siskohat sesuai dengan data dan teori yang digunakan.

Penelitian ini menggunakan objek penelitian SISKOHAT (Sistem Komputerisasi Haji Terpadu) sebagai aplikasi pembayaran biaya penyelenggaraan ibadah haji dan operasional haji terkomputerisasi. Penelitian ini berusaha meneliti keberhasilan implementasi SISKOHAT di Kantor Wilayah Kementerian Agama Provinsi DIY dengan Model Kesuksesan Sistem Informasi DeLone dan McLean, dengan mendasarkan pada 6 Pengukuran yaitu: 1. Kualitas sistem, 2. Kualitas informasi, 3. Kepuasan pemakai, 4. Penggunaan, 5. Dampak individu, 6. Dampak organisasi.Penelitian ini bertujuan untuk mengetahui sejauh mana keberhasilan penerapan SISKOHAT (Sistem Informasi dan Komputerisasi Haji Terpadu) di Kantor Wilayah Kementerian Agama Provinsi DIY berdasarkan model kesuksesan Delone dan McLean.

Kedua, penelitian yang disusun oleh Putra Aulia (Tahun 2013) dengan judul "Sistem Informasi Data Jama'ah Haji pada Kantor Kementerian Agama Kabupaten Bireuen Berbasis WEB". Penelitian ini menguraikan tentang bagaimana membangun sebuah sistem informasi yang mampu mengelola data jama'ah haji pada Kantor Kementerian Agama Kabupaten Bireuen berbasis WEB yang mudah diaplikasikan oleh petugas pelaksana haji dan pengelolaan data penyelenggaraan ibadah haji.

Teknik pengumpulan data yang digunakan oleh penulis adalah dengan mengadakan studi kepustakaan untuk mendapatkan bahan seperti buku-buku dan informasi lain yang berhubungan dengan permasalahan, dan dengan cara wawancara langsung dengan karyawan/ pegawai pada Kementerian Agama Kabupaten Bireuen guna memperoleh keterangan atau informasi yang berhubungan dengan penulisan ini. Hasil penelitian 
menunjukkan bahwa dengan adanya Sistem Pengolahan Data Jama'ah Haji pada Kantor Kementerian Agama Kabupaten Bireuen Berbasis Web, maka proses penginputan maupun pencarian data jama'ah haji dapat dilakukan dengan lebih cepat, akurat dan sesuai dengan tuntutan semua pihak.

Ketiga, penelitian yang disusun oleh Khairunnisa' Rio Fahlefi (Tahun 2014) dengan judul "Sistem Informasi Manajemen atas Pembiayaan Dana Talangan Haji dalam Upaya Meningkatkan Manajemen Kontrol pada Bank Muamalat Indonesia Cabang Pembantu Tulungagung". Penelitian ini menggunakan metode penelitian kualitatif dengan pendekatan deskriptif. Jenis penelitian yang digunakan dalam penelitian skripsi ini adalah penelitian lapangan. Sumber data yang diperoleh yaitu data primer dan data sekunder. Teknik pengumpulan data pada penelitian ini adalah wawancara, observasi dan dokumentasi. Sedangkan teknik analisis data yang digunakan adalah pola interaktif yang meliputi; reduksi data, penyajian data dan penarikan kesimpulan.

Hasil dari penelitian ini adalah sebagai berikut: 1. Sistem dan prosedur pembiayaan dana talangan haji pada Bank Muamalat Indonesia (BMI) Cabang Pembantu (Capem) Tulungagung adalah; (a) Nasabah Calon Jemaah Haji $(\mathrm{CJH})$ membuka rekening tabungan haji di BMI Tulungagung, (b) $\mathrm{CJH}$ mendatangi Kantor Kementerian Agama (Kankemenag) Kabupaten/ Kota untuk melakukan pendaftaran haji dan mendapatkan SPPH (Surat Pengantar Pergi Haji), (c) SPPH tersebut dientry oleh bank untuk mendapatkan porsi/ seat haji, (d) cek kesehatan di Puskesmas, (e) melaporkan ke Kankemenag Kabupaten/ Kota untuk dicatat sebagai calon jama'ah haji yang sudah terdaftar pelunasannya. 2. Sistem informasi manajemen atas pembiayaan dana talangan haji pada Bank Muamalat Cabang Pembantu Tulungagung dalam upaya meningkatkan menajemen kontrol adalah menggunakan 2 (dua) aspek, yaitu; (1) aspek teknologi, yang meliputi; perangkat komputer yang memadai, program aplikasi pembiayaan dana talangan haji, konektivitas, bahasa pemograman, kemudahan akses, pemeliharaan komputer, dan sistem pengaman data. Dan (2) aspek sumber daya manusia, yang meliputi; penguasaan teknologi informasi, pengetahuan tentang pembiayaan dana talangan haji, pelatihan SDM, kinerja SDM dan kualitas pelayanan. 


\section{Analisis Hasil Penelitian}

\section{Efektivitas Sistem Informasi dan Komputerisasi Haji Terpadu (SISKOHAT)}

Penyelenggaraan ibadah haji di Indonesia dari tahun ke tahun mengalami peningkatan jumlah pendaftar yang sangat signifikan, sehingga menuntut pemerintah untuk mengupayakan pelayanan terbaik dan berkualitas setiap tahunnya. Dalam meningkatkan pelayanan penyelenggaraan ibadah haji, Kementerian Agama menumbuh kembangkan sistem pendataan palayanan haji melalui pemanfaatan pelayanan teknologi informasi dan komunikasi yang dilakukan di Tanah Air dan Arab Saudi yang disebut Sistem Informasi dan Komputerisasi Haji Terpadu (SISKOHAT).

Pembangunan siskohat dirancang untuk meningkatkan kualitas pelayanan ibadah haji secara signifikan. Dengan adanya sistem yang terintegrasi dan terpusat memperkecil kemungkinan kesalahan dalam pengisian data atau melakukan kecurangan dalam penetapan nomor porsi calon untuk jamaah haji. Siskohat juga membantu mempercepat proses pembukaan rekening awal pada bank BPS BPIH yang telah ditetapkan hingga mendapatkan nomor porsi haji.

Sistem Informasi dan Komputerisasi Haji Terpadu (SISKOHAT) merupakan suatu sistem pelayanan pendataan konvensional menuju ke arah automasi secara online dan Real Time antara 17 Bank Penerima Setoran Biaya Perjalanan Ibadah Haji (BPS-BPIH) dan Kantor Kementrian Agama di 33 Provinsi di seluruh Indonesia dengan pusat komputer di Kementerian Agama Pusat. Siskohat mencakup dukungan terhadap seluruh prosesi penyelenggaraan haji, mulai dari pendaftaran haji, pemrosesan dokumen-dokumen perjalanan ibadah haji, proses pemberangkatan/ Embarkasi sampai dengan proses kepulangan ke Tanah Air/ Debarkasi.11

Data yang masuk dari masing-masing Kementerian Agama Kabupaten di saring dan di validasi oleh Kantor Wilayah Kementerian Agama masing-masing provinsi dan diteruskan ke Kementerian Agama Pusat. Dengan adanya sistem data yang terintegrasi merupakan terobosan yang sangat efektif dalam meningkatkan kualitas pelayanan penyelenggaraan ibadah haji dan umroh di Kementerian Agama dalam

11Islamika Zulfiana, "Pembuatan Rencana Strategis SI/ TI Bidang Penyelenggaraan Haji dan Umroh Kantor Wilayah Kementerian Agama Daerah Istimewa Yogyakarta”, Jurnal Informatika, Maret, 2014, Hlm.2 
menangani persoalan-persoalan haji yang menyangkut ribuan calon jamaah haji. Mulai dari proses pendataan calon jamaah haji yang baru mendaftar, pengeluaran nomor porsi untuk menentukan tahun keberangkatan ribuan calon jamaah haji, pelunasan biaya pendaftaran yang langsung terintegrasi dengan 17 Bank Penerima Setoran (BPS) secara online sehingga langsung bisa terdeteksi apabila calon jamaah haji melakukan konfirmasi ke kementerian agama hingga persoalan yang menyangkut dokumen perjalanan ibadah haji seperti paspor, visa dan lain sebagainya.

Keberadaan SISKOHAT saat ini memberikan kontribusi yang besar dalam pelayanan penyelenggaraan Ibadah Haji di Indonesia, SISKOHAT mempunyai beberapa fungsi : 1) Pendaftaran dan penyimpanan database jemaah dan petugas.Ketersediaan database jamaah haji yang semakin terstruktur, dapat mempermudah dan mempercepat melakukan kesiapankesiapan dan penyediaan pelayanan akomodasi atau transportasi lebih lanjut; 2) Pendaftaran haji dapat dilakukan sepanjang tahun (non stop); 3) Pemrosesan dokumen paspor dan pemvisaan; 4) Penerbitan Dokumen Administrasi Perjalanan Ibadah Haji (DAPIH); 5) Pembayaran BPIH oleh BPS BPIH secara online dan pada waktu yang bersamaan (realtime) langsung dapat dihitung jumlah total dana keuangan setoran BPIH yang tersimpan di setiap BPS BPIH; 6) Pelaksanaan sistem akuntansi BPIH; 7) Proses pembatalan; 7) Penyusunann manifest dan kelompok terbang (kloter); 8) Pemantauan (monitoring) On Time Performance (OTP) penerbangan; 9) Pemantauan kesehatan jemaah haji; 10) Pemantauan operasional haji di Tanah Air dan di Arab Saudi. ${ }^{12}$

Disamping itu Siskohat mampu memberikan pencepatan, ketepatan, dan keakuratan pelayanan secara otomatis sejak masa pendaftaran, penyelesaian administrasi, dan dokumen sampai pada masa operasional di Embarkasi dan di Arab Saudi. ${ }^{13}$ Efektivitas Penerapan Sistem Informasi dan Komputerisasi Haji Terpadu (SISKOHAT) di Kantor Wilayah Kementerian Agama Provinsi Jawa Tengah dipengaruhi oleh beberapa faktor, yaitu ;

\section{a. Kecanggihan sistem}

Pembaharuan sistem informasi serta kecanggihan teknologi dari tahun ke tahun merupakan salah satu penunjang keberhasilan Sistem

\footnotetext{
12Wawancara dengan Tim SISKOHAT Kantor Wilayah Kementerian Agama Provinsi Jawa Tengah, 30-6-2015

13Departemen Agama RI, Bunga Rampai Perhajian, (Jakarta: Dirjend Bimas Islam, 1998), hlm. 23
} 
Informasi dan Komputerisasi Haji Terpadu (SISKOHAT) dalam pengelolaan penyelenggaraan ibadah haji dan umroh di seluruh Indonesia.

Dengan format webbase termutakhir yang baru diresmikan oleh Kementerian Agama Pusat pada tanggal 3 April 2014 memberikan kemudahan-kemudahan dalam pengumpulan data, pengolahan data serta ketepatan penyajian informasi. Tampilan web yang menarik serta tampilan menu yang lebih banyak daripada sebelumnya memudahkan para pegawai dalam mengoperasikan sistem komputer beserta komponennya. Sistem informasi dan komputerisasi haji terpadu (siskohat) terbaru merupakan perbaikan dari sistem sebelumnya yaitu siskohat Gen-1 yang masih berbasis text base beralih ke web base yang lebih mudah diakses dan memiliki menu yang lebih komplek. Selain dari segi tampilan, platform dan sistem database-nya juga diperbaharui sehingga lebih real time serta mampu memisahkan analisis dan transaksi yang terjadi dalam penyelenggaraan ibadah haji di Kanwil Kemenag Provinsi Jawa Tengah.

Kecanggihan teknologi dan komunikasi dengan berbasis konektivitas sistem online serta penyediaan informasi yang real time mendorong Kementerian Agama di berbagai daerah untuk selalu menyajikan pelayanan serta menyajikan informasi secara terbaharukan dan terakses langsung oleh seluruh calon jamaah haji serta masyarakat luas pengguna jasa.

\section{Gambar 1}

Sistem Informasi dan Komputerisasi Haji Terpadu Generasi 2

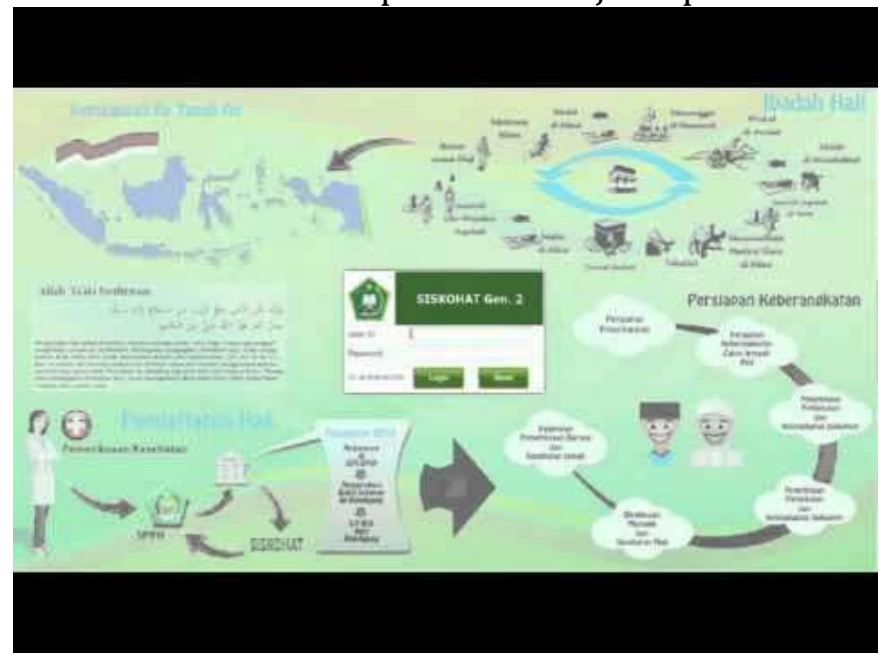

Sumber : Arsip Seksi Informasi Bidang Penyelenggara Haji dan Umroh Kantor Wilayah Kementerian Agama Provinsi Jawa Tengah. 
Gambar 2

Sistem Informasi dan Komputerisasi Haji Terpadu versi lama

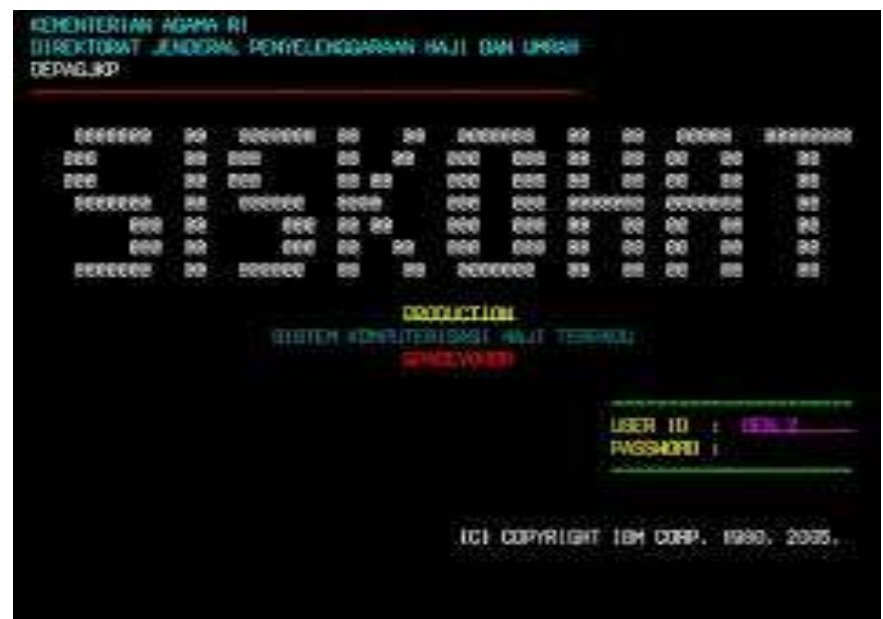

Sumber : Arsip Seksi Informasi Bidang Penyelenggara Haji dan Umroh

Kantor Wilayah Kementerian Agama Provinsi Jawa Tengah

\section{b. Sarana dan fasilitas sistem informasi}

Kelengkapan fasilitas serta sarana prasana di ruang Sistem Informasi dan Komputerisasi Haji Terpadu (SISKOHAT) sangat mempengaruhi efektivitas kinerja civitas pegawai dalam menghasilkan pelayanan yang prima serta keakuratan informasi yang diterima oleh seluruh masyarakat.

Ruang yang kondusif, dan perangkat komputer serta komponen yang mendukung seperti, kamera, finger print, rooter, switch hub, printer, sambungan internet, merupakan satu kesatuan yang saling terintegrasi dalam menghasilkan kualitas ketepatan pengumpulan data serta penyajian data. Integrasi data yang berasal dari berbagai daerah perlu adanya sarana dan prasarana yang dapat menampung, menyimpan dalam bentuk database dan sekaligus dapat dipanggil atau ditemukan kembali secara mudah jika sewaktu-waktu dibutuhkan.

\section{c. Sumber daya manusia atau tenaga ahli}

Adanya pembangunan infrastruktur sistem informasi dan komputerisasi haji terpadu di Kementerian Agama perlu diikuti dengan pemberdayaan sumber daya manusia (SDM) secara memadai dan 
professional ${ }^{14}$. Sumber daya manusia dalam pengendalian sistem informasi penyelenggaraan ibadah haji memegang peranan yang sangat penting, karena tanpa adanya sumber daya manusia yang mumpuni sesuai dengan kualifikasi bidang informasi dan komputer, maka suatu sistem yang terintegrasi sangat sulit dijalankan.

\section{d. Standar operasional yang berlaku}

Dalam rangka optimalisasi pengelolaan serta penyediaan Sistem Informasi dan Komputerisasi Haji Terpadu (SISKOHAT) yang berorientasi pada taat asas dan kinerja maka Kementerian Agama memandang perlu menyusun suatu Standar Operasional Prosedur (SOP). Penyusunan SOP SISKOHAT dimaksudkan sebagai suatu kesatuan dalam dokumen Standar Manajemen Mutu (SMM) penyelenggaraan ibadah haji dan umroh, yang di harapkan nantinya bagian dari persyaratan untuk memperoleh ISO 9001:2008. SOP disusun dalam rangka menjadi acuan untuk melaksanakan tugas secara efektif dan efisien.

Dengan demikian pengelolaan Sistem Informasi dan Komputerisasi Haji Terpadu (SISKOHAT) benar-benar dapat terlaksana tepat sesuai dengan tujuan yang diharapkan sebagai pendukung keberhasilan penyelenggaraan ibadah haji dan umroh baik di Tanah Air maupun di Arab Saudi sekaligus dapat menjadi standar petunjuk penilaian keberhasilan pelayanan berdasarkan indikator kinerja menuju terwujudnya tata kelola kepemerintahan yang baik (good governance).

Sistem Informasi dan Komputerisasi Haji Terpadu (Siskohat) merupakan unsur penyangga berbagai jenis pelayanan ibadah haji. Siskohat sebagai jantung penyelenggaraan ibadah haji yang telah mengintegrasikan elemen-elemen terpenting dalam penyelenggaraan ibadah haji, yakni pendaftaran haji, dokumen haji dan keuangan haji. Tingginya jumlah pendaftar di tiap-tiap daerah menyebabkan fungsi siskohat semakin vital.

Sistem informasi dan komputerisasi haji terpadu dinilai efektif dan mempunyai nilai aplikatif yang tinggi apabila sistem tersebut mampu memberikan kontribusi nyata dalam memperlancar pelayanan penyelenggaraan ibadah haji dan umroh di Kementerian Agama yang meliputi :

${ }^{14}$ Departemen Agama, Standarisasi Pusat Informasi Haji (PIH), (Jakarta: Dirjend Bimas Islam, 2005), hlm.109 


\section{1) Signifikansi informasi}

Sistem Informasi dan Komputerisasi Haji Terpadu ibarat darah segar yang mengalir dalam tubuh pelayanan penyelenggaraan ibadah haji di Kementerian Agama. Banyaknya calon jamaah haji dari berbagai latar belakang yang mendaftar pada tiap tahunnya menuntut Kementerian Agama memberikan pelayanan optimal serta informasi yang akurat yang dapat diakses dengan mudah oleh berbagai pihak. Hal ini diharapkan mampu memudahkan para calon jamaah haji dalam mengakses informasi kapanpun, dimanapun sehingga tidak perlu membutuhkan banyak waktu untuk sekedar menanyakan informasi kepastian pemberangkatan, persyaratan pendaftaran ataupun kepentingan informasi lainnya. Karna pada dasarnya fungsi utama informasi adalah menambah pengetahuan serta mengurangi ketidakpastian pemakai informasi dalam mendapatkan informasi tentang pelayanan penyelenggaraan ibadah haji dan umroh. Signifikansi informasi pelayanan penyelenggaraan ibadah haji meliputi:

\section{2) Validitas informasi yang diterima}

Calon jamaah haji sangat terbantu dengan adanya penyempurnaan pelayanan yang semakin meningkat tiap tahunnya. Sistem Informasi dan Komputerisasi Haji Terpadu (SISKOHAT) mempermudah para jamaah dalam melakukan semua aktifitas yang berkaitan dengan sistem pelayanan ibadah haji mulai dari pendaftaran ibadah haji, pengeluaran nomor porsi, informasi tahun keberangkatan yang dapat diakses kapanpun dan dimanapun melalui website resmi Kementerian Agama. Informasi yang disajikanpun sangat terpercaya sehingga calon jamaah haji merasa tidak poerlu menghabiskan banyak waktu untuk sekedar mencari info tahun keberangkatan dan info-info lain yang menyangkut pelayanan penyelenggaraan ibadah haji dan umroh.

\section{3) Informasi yang tepat waktu}

Merupakan informasi yang tiba pada manajer/pengambil keputusan sebelum suatu keputusan diambil. Seperti halnya keputusan pengeluaran nomor porsi, informasi yang diterima terkait informasi data calon jamaah haji hingga informasi dari Bank Penerima Setoran awal haji tepat pada waktu yang dibutuhkan.

\section{4) Informasi yang relevan}

Sebuah informasi yang disampaikan harus relevan, yakni informasi yang dikeluarkan baik dari kantor Kementerian Agama Pusat, Kementerian Agama Kota hingga informasi yang dikeluarkan dari situs resmi 
Kementerian Agama adalah sesuai dengan apa yang dibutuhkan oleh jamaah haji seputar informasi pelayanan ibadah haji.

\section{5) Informasi yang bernilai}

Pemakaian informasi merupakan suatu komponen yang tak dapat dipisahkan dari pengelolaan sistem informasi itu sendiri, karena mereka itulah yang sesungguhnya mendayagunakan produk informasi tersebut sesuai dengan kebutuhannya. Hal ini berarti produk informasi dapat dinyatakan bermanfaat/ bernilai, bila informasi itu memenuhi kebutuhan pihak pemakainya. ${ }^{15}$

\section{6) Informasi yang dapat dipercaya.}

Informasi merupakan Rangkaian data yang sudah siap dipakai sebagai dasar monitoring, evaluasi dan pengambilan keputusan. Oleh karena itu, informasi yang akurat dan dapat dipercaya mutlak dibutuhkan. Kesalahan dalam penyampaian informasi merupakan masalah yang besar dalam sistem informasi manajemen. Dalam kebanyakan sistem informasi, penerima informasi tidak mempunyai pengetahuan, baik tentang penyimpangan maupun tentang kesalahan yang dapat mempengaruhi kualitasnya.

\section{7) Kegunaan spesifiknya, termasuk mendukung proses pengambilan keputusan}

Sistem Informasi dan Komputerisasi Haji Terpadu dibangun untuk mendukung proses pengambilan keputusan serta mamberikan kemudahan dan kecepatan layanan, yang meliputi: pengendalian pendaftaran dan penyetoran lunas Biaya Penyelenggaraan Ibadah Haji (BPIH), pengendalian kuota haji nasional secara tersistem, kepastian pergi haji pada tahun berjalan, serta adil secara berurutan untuk memperoleh nomor porsi haji. ${ }^{16}$

Keberadaan SISKOHAT saat ini memberikan kontribusi yang besar dalam pelayanan Haji dan Umrah di Indonesia. Sistem Informasi dan Komputerisasi Haji Terpadu mempunyai beberapa fungsi sebagai salah satu pendukung proses pengambilan keputusan dalam pelayanan penyelenggaraan ibadah haji di Kantor Wilayah Kementerian Agama Provinsi Jawa Tengah, sebagai berikut :

\footnotetext{
${ }^{15}$ Tata Sutabri, Sistem Informasi Manajemen, (Yogyakarta: Andi, 2005), hlm.38

${ }^{16}$ wawancara dengan Kepala Seksi Penyelenggara Ibadah Haji dan Umroh kantor Wilayah Kementerian Agama Provinsi Jawa Tengah, 18-6-2015
} 


\section{1) Pendaftaran}

Sistem Informasi dan Komputerisasi Haji Terpadu menjadi sarana untuk mendata seluruh pendaftaran haji sehingga dapat diperoleh database jemaah haji. Sistem ini memberikan nomor porsi kepada setiap pendaftar sesuai dengan nomor antrian dengan prinsip first come first served. Pendataan haji melalui SISKOHAT dilakukan sepanjang tahun yang dapat dimonitor dan dikendalikan setiap saat secara real time. Database pendaftaran yang tersimpan di SISKOHAT juga dapat difungsikan untuk mempermudah dan mempercepat penyiapan dokumen, mempercepat pengelompokkan pramanifest kloter, kepastian mengeluarkan Surat Panggilan Masuk Asrama haji di embarkasi, mempermudah akuntansi pelaporan BPIH serta living cost, menjadi acuan pembuatan identitas jemaah haji, penyediaan akomodasi, konsumsi di embarkasi maupun di Arab Saudi serta sebagai alat control/cross check dalam memfilter berbagai penyalahgunaan data jemaah haji.

\section{2) Database Dokumen Haji}

Siskohat memiliki fungsi sebagai penyimpan database yang digunakan untuk mempermudah dan mempercepat penyiapan dokumen paspor bagi jemaah haji dan mempercepat pemvisaan secara online dengan Kedutaan Besar Saudi Arabia di Jakarta. Dalam rangka pengendalian dan pelayanan jemaah haji di Arab Saudi yang semula terdapat pada paspor haji (cokelat), Kementerian Agama mulai mengembangkan database SISKOHAT dengan mengikuti format dan struktur database imigrasi untuk mencetak dan menerbitkan Dokumen Administrasi Perjalanan Ibadah Haji yang dilakukan secara online dengan SISKOHAT.

\section{3) Akuntansi BPIH}

Database SISKOHAT juga berfungsi memberikan dukungan dalam pelaksanaan sistem akuntansi BPIH dan menjadi alat cross check kesesuaian antara pendaftar haji dengan jumlah dana setoran BPIH pada rekening Kementerian Agama di setiap BPS BPIH. Terdapat beberapa jenis setoran BPIH yang terkait langsung dengan database SISKOHAT meliputi antara lain: setoran awal dan pelunasan BPIH, pembatalan, serta pelaporan setiap tutup buku harian, bulanan dan tahunan. Dalam rangka pengelolaan belanja operasional dengan dana BPIH, database SISKOHAT juga menjadi pendukung dalam penyusunan rencana belanja BPIH, realisasi penggunaan dana untuk setiap komponen BPIH dan pelaporan akhir. Database SISKOHAT dapat dijadikan sebagai sarana penunjang pengendalian dan pengawasan terhadap pelimpahan setoran BPIH oleh 17 BPS BPIH. Oleh 
Karena itu, sedang dikembangkan aplikasi switching yang dapat mendukung sistem akuntansi BPIH. Pendaftaran setoran awal BPIH sebesar Rp. 20.000.000 dimulai sejak tanggal 1 Juni 2004 dan dilakukan perubahan besaran setoran awal BPIH sebesar Rp. 25.000.000 dimulai pada tanggal 3 Mei 2010. Jumlah pendaftar seluruh indonesia sampai dengan hari Rabu, 17 Juni 2015 pukul 12:27 WIB sebanyak 2.847.540 orang, dengan jumlah pendaftar di Provinsi Jawa Tengah mencapai 458.650 orang sehingga dengan adanya peningkatan pendaftar calon jamaah haji maka kondisi waiting list pun meningkat hingga 19 tahun. ${ }^{17}$

\section{4) Database transportasi haji}

SISKOHAT berfungsi pula sebagai pendukung database transportasi haji yang diintegrasikan dengan pihak maskapai penerbangan untuk mempermudahkan pembagian Kelompok Terbang (Kloter) jemaah, penyusunan pra manifest serta penyiapan boarding pass penerbangan sampai dengan penempatan seat setiap kolter dan mutasi kloter. SISKOHAT memiliki aplikasi yang mampu mengolah jadwal penerbangan dan memonitor On Time Performance (OTP) penerbangan jemaah baik pada saat pemberangkatan dan pemulangan jamaah haji. Dengan demikian, status dan posisi jemaah haji di setiap bandara baik di embarkasi maupun Arab Saudi dapat segera diketahui.

\section{5) Database penempatan pemondokan jemaah}

Pengelompokkan jemaah ke dalam kloter dibentuk melalui database SISKOHAT di setiap embarkasi. Jumlah jemaah dan kloter menjadi dasar dalam menentukan penempatan jemaah haji pada setiap pemondokan arab Saudi dapat dimonitor melalui SISKOHAT. Disamping itu, database SISKOHAT juga dapat mendukung proses Qur'ah untuk penempatan jemaah haji di pemondokan Makkah, termasuk dukungannya terhadap ketepatan dan keakuratan data jemaah haji yang diasumsikan memperoleh pengembalian selisih sewa rumah di Arab Saudi.

\section{6) Informasi publik}

Sebagaimana diketahui bersama bahwa database SISKOHAT dapat diakses secara terbuka bagi kepentingan informasi publik melalui website http:// haji.kemenag.go.idmaupun melalui terminal yang tersambung dengan jaringan SISKOHAT baik di Kementerian Agama pusat dan daerah, instansi terkait dan Arab Saudi. Dalam rangka informasi publik seluruh jemaah yang masuk dalam kuota tahun berjalan, nama dan alamat

17Observasi, 18-6-2015 
Penyelenggara Ibadah Haji Khusus (PIHK), serta berita perhajian dapat diakses secara luas. Pada saat operasional haji, informasi publik diperluas melalui kegiatan Media Center Haji (MCH).

\section{7) Sistem informasi kesehatan haji}

Database SISKOHAT telah memiliki variable data terkait dengan kebutuhan layanan kesehatan jemaah haji, meliputi data jemaah risiko tinggi (Risti), hasil pemeriksaan kesehatan jemaah di embarkasi, sehingga dapat membantu petugas kesehatan dalam melakukan pelayanan medis selama masa operasional haji di embarkasi maupun di Arab Saudi. Di samping itu, SISKOHAT juga memiliki aplikasi untuk pendataan dan informasi bagi pelayanan kesehatan terkait dengan jemaah haji sakit rawat jalan, rawat inap, rujukan, dan jemaah haji wafat. Data tersebut dapat digunakan untuk melakukan analisis terhadap tingkat pengamanan kesehatan bagi jemaah haji Indonesia untuk setiap musim haji. Pihak Kementerian Kesehatan juga memliki koneksitas antara sistem TI kesehatan dengan jaringan SISKOHAT, sehingga seluruh database SISKOHAT sepenuhnya dapat dimanfaatkan oleh layanan kesehatan sejak di tanah air sampai di Arab Saudi.

\section{8) Database petugas haji}

Data petugas haji Indonesia seluruhnya di masukkan ke dalam database Siskohat, baik petugas kesehatan Tim Kesehatan Haji Indonesia (TKHI) yang direkrut oleh Kementerian Kesehatan, maupun petugas pelayanan umun Tim Petugas Haji Indonesia (TPHI) dan petugas pelayanan ibadah Tim Pembimbing Ibadah Haji Indonesia (TPIHI) yang direkrut oleh Kementerian Agama. Database petugas haji yang tersimpan dan menyatu dalam database SISKOHAT dapat menjadi dasar untuk penyajian informasi tentang profil petugas haji Indonesia pada setiap musim haji. Disamping itu, data petugas tersebut dapat dimanfaatkan untuk melakukan analisis dan bahan pertimbangan dalam penentuan petugas haji pada tahun berikutnya.

\section{9) Hubungan informasi tersebut dengan informasi lain.}

Informasi database calon jamaah haji yang terstruktur hingga informasi penyetoran dana awal di 17 BPS BPIH yang terintegrasi sangat mempermudah Kementerian Agama dalam melakukan kesiapan-kesiapan dalam penyelenggaraan ibadah haji. Hubungan informasi satu dengan informasi yang lain juga memudahkan Kementerian Agama dalam penyediaan pelayanan akomodasi serta transportasi lebih lanjut, seperti 
pembuatan dokumen paspor dan pemvisaan, pengelompokan pramanifest untuk penentuan kloter, kepastian pengeluaran SPMA (Surat Panggilan Masuk Asrama) di embarkasi embarkasi setempat, hingga menjadi alat kontrol / cross check dalam memfilter berbagai manipulasi serta menjadi acuan pembuatan identitas jamaah haji maupun dalam penyediaan akomodasi, konsumsi, dan living cost lebih dini di embarkasi maupun di Arab Saudi.

\section{Faktor Pendukung dan Penghambat}

Dalam setiap pelaksanaan sebuah kelembagaan/ organisasi pemerintahan, ada beberapa faktor yang dapat mendukung serta menghambat penerapan sistem informasi dan komputerisasi haji terpadu sebagai lembaga penyelenggara ibadah haji dan umroh. Adanya faktor pendukung penerapan Sistem Informasi dan Komputerisasi Haji Terpadu (SISKOHAT) menjadikan Sistem Informasi dan Komputerisasi Haji Terpadu (SISKOHAT) tersebut berjalan secara efektif, sebaliknya faktor penghambat Sistem Informasi dan Komputerisasi Haji Terpadu (SISKOHAT) sebagai alat koreksi untuk memaksimalkan peningkatan pelayanan penyelenggaraan ibadah haji. Adapun dukungan dan hambatan yang dialami oleh siskohat Kantor Wilayah Kementerian Agama Provinsi Jawa Tengah meliputi:

Faktor pendukung penerapan Sistem Informasi dan Komputerisasi Haji Terpadu (SISKOHAT) di Kantor Wilayah Kementerian Agama Provinsi Jawa Tengah yaitu : Pertama, penyempurnaan tools yang berbasis web base dengan tampilan menu yang lebih banyak sehingga memudahkan para pegawai untuk mengakses berbagai aplikasi sesuai dengan kebutuhan programnya dan tidak perlu menggunakan komputer khusus untuk mengakses tools tersebut.

Kedua, sistem informasi dan komputerisasi haji terpadu yang terintegrasi dengan berbagai Kementerian agama Kabupaten/Kota dan Bank Penyelenggara Penerima Setoran (BPPS) memudahkan pemerintah dalam melakukan proses pendataan dan pemantauan mulai dari pendaftaran calon jamaah haji, pembayaran, pembatalan ataupun seluruh aktifitas penyelenggaraan ibadah haji dengan cepat dan tepat. Sehingga data rekapitulasi jumlah calon jamaah haji yang masuk setiap harinya dari seluruh indonesia langsung tersimpan di host siskohat Kementerian Agama Pusat tanpa memerlukan proses yang lama.

Ketiga, pengendalian utama sistem informasi dan komputerisasi haji terpadu menggunakan Centralized Data Processing (CDP), dimana semua proses pengolahan data penyelenggaraan ibadah haji berada di pusat. 
Dengan menggunakan pengolahan data seperti ini dapat mengurangi resiko duplikasi pada data yang tersimpan sehingga data penyelenggaraan ibadah haji yang masuk benar-benar terjaga keamanannya.

Adapun faktor penghambat penerapan sistem informasi dan komputerisasi haji terpadu (Siskohat) di Kantor Wilayah Kementerian Agama Provinsi Jawa Tengah yaitu : Pertama, dari segi penyimpanan data, sistem informasi dan komputerisasi haji terpadu Kementerian Agama di seluruh Indonesia menggunakan sistem centralized data processing (CDP). Sistem centralized data processing (CDP) ini menggunakan komputer host siskohat sebagai wadah penyimpanan seluruh database haji serta sebagai pengendali utama proses pengolahan database haji yang terpusat di satu tempat yaitu di Kementerian Agama Pusat (Jakarta).

Kedua, apabila sistem ini terjadi kerusakan ataupun gangguan akan mengakibatkan offline pada proses pengolahan data sehingga BPS BPIH yang disebut sebagai user pun tidak dapat mengakses data untuk sementara waktu. Meskipun demikian, pemerintah tetap mengantisipasi agar dapat mencegah kejadian-kejadian yang dapat menghambat kinerja sistem informasi dan komputerisasi haji terpadu sehingga pelayanan hajipun dapat dilakukan secara maksimal.

Ketiga, bandwidth yang terlalu kecil. Bandwidth adalah nilai hitung atau perhitungan konsumsi transfer data telekomunikasi yang dihitung dalam satuan bit per detik atau yang biasa disingkat bps yang terjadi antara komputer server dan komputer client dalam waktu tertentu dalam sebuah jaringan komputer. Bandwidth sendiri akan dialokasikan ke komputer dalam jaringan dan akan mempengaruhi kecepatan transfer data pada jaringan komputer tersebut. Ketika sebuah website diakses, maka bandwidth account akan berkurang sebesar halaman yang di akses (dalam ukuran Byte). Website dengan banyak gambar dan video tentu akan lebih cepat menghabiskan bandwidth dibanding website yang menampilkan teks dan gambar. Dengan tools sistem informasi dan komputerisasi haji terpadu (siskohat) terbaru di Kementerian Agama yang berbasis web base dengan berbagai fitur serta berbagai gambar, sangat membutuhkan kapasitas bandwidt yang lebih besar. Karna semakin besar Bandwidth pada jaringan komputer maka semakin cepat pula kecepatan transfer data yang dapat dilakukan oleh client maupun server. Akan tetapi apabila kapasitas bandwidt terlalu kecil yang tidak sebanding dengan aktifitas web maka kecepatan transfer data yang dilakukan server maupun client akan terhambat (loading lambat).

Keempat, minimnya sumber daya manusia yang mumpuni di bidang informasi dan pengelolaan komputer. Jumlah pegawai yang mampu 
mengoperasikan sistem informasi dan komputerisasi haji terpadu di Kantor Wilayah Kementerian Agama Provinsi Jawa Tengah hanya sebagian kecil. Hal ini dipengaruhi oleh faktor usia pegawai yang rata-rata sudah mencapai 35 tahun ke atas, sehingga untuk mengikuti perkembangan teknologi terkini sedikit terhambat. Akibatnya apabila ada kendala di bagian sistem informasi, dan tim siskohat sedang bertugas di luar kantor maka pelayanan sistem informasi terhambat untuk sementara waktu. Upaya peningkatan kemampuan mengenai teknologi informasi seluruh pegawai terus digalakkan dengan adanya program kerja pelatihan skill komputer dalam penetapan program kerja tahunan di Kantor Wilayah Kementerian Agama Provinsi Jawa Tengah. Kegiatan tersebut diharapkan mampu menambah skill serta wawasan seluruh pegawai tentang teknologi terkini sistem informasi, sehingga seluruh pegawai minimal mampu mengoperasikan salah satu program di sistem informasi dan komputerisasi haji terpadu.

Kelima, belum terbentuknya acuan Standar Operasional Prosedur (SOP) khusus Sistem Informasi dan Komputerisasi Haji Terpadu (SISKOHAT) Kantor Wilayah Kementerian Agama Provinsi Jawa Tengah sehingga dalam pelaksanaanya masih mengacu pada penggunaan Standar Operasional Prosedur (SOP) masing masing item.

\section{Simpulan dan Rekomendasi}

Dari hasil pengumpulan data melalui observasi, dokumentasi dan wawancara serta setelah dilakukan analisadengan memperhatikan pokokpokok permasalahan yang diangkat dengan judul Efektivitas Sistem Informasi dan Komputerisasi Haji Terpadu (SISKOHAT) dalam Penyelenggaraan Ibadah Haji di Kantor wilayah Kementerian Agama Provinsi Jawa Tengah, maka kesimpulan yang diperoleh dari penelitian ini adalah:

Pertama, Sistem Informasi dan Komputerisasi Haji Terpadu (SISKOHAT) dalam penyelenggaraan ibadah haji di Kantor Wilayah Kementerian Agama Provinsi Jawa Tengah telah berlangsung secara efektif. Hal ini dapat dibuktikan dengan berjalannya berbagai macam fungsi sistem informasi dan komputerisasi haji terpadu dengan maksimal, seperti : 1) Proses pendaftaran dan penyimpanan database seluruh jamaah dan petugas haji lebih cepat dan tertata rapi; 2) Mempercepat pemrosesan dokumen paspor, visa, serta penerbitan Dokumen Administrasi Perjalanan Ibadah Haji (DAPIH); 3) Proses pembayaran setoran awal dan biaya pelunasan di BPS BPIH secara online dan real time lebih akuntabel; 4) 
Penyusunan Pramanifest dan Klompok Terbang (Kloter) lebih mudah dan cepat sesuai dengan data yang masuk; 5) Pemantauan (monitoring) kesehatan jamaah haji serta On Time Performance (OTP) penerbangan berlangsung secara optimal; 6) Pemantauan operasional ibadah haji di Tanah Air sampai di Arab Saudi lebih terkontrol, sehingga kekurangankekurangan dalam penyelenggaraan ibadah haji dapat terdeteksi sedini mungkin.

Kedua, penerapan Sistem Informasi dan Komputerisasi Haji Terpadu (SISKOHAT) di Kantor Wilayah Kementerian Agama Provinsi Jawa Tengah tidak lepas dari faktor pendukung serta faktor penghambat. Akan tetapi, adanya faktor penghambat penerapan sistem informasi dan komputerisasi haji terpadu (SISKOHAT) tersebut, tidak menjadikan penghalang dalam meningkatkan pelayanan penyelenggaraan ibadah haji. Pemerintah tetap mengantisipasi agar dapat mencegah kejadian-kejadian yang dapat menghambat keefektifan sistem informasi dan komputerisasi haji terpadu. 


\section{DAFTAR PUSTAKA}

Al-'aqil, Tholal Bin Ahmad, Petunjuk Bagi Jamaah Haji dan Umroh, (1427H). Arsip Kantor Wilayah Kementerian Agama Provinsi Jawa Tengah.

Departemen Agama RI, Bunga Rampai Perhajian, (Jakarta: Dirjend Bimas Islam, 1998).

Departemen Agama RI, Standarisasi Pusat Informasi Haji (PIH), (Jakarta: Dirjend Bimas Islam, 2005).

Islamika Zulfiana, "Pembuatan Rencana Strategis SI/TI Bidang Penyelenggaraan Haji dan Umroh Kantor Wilayah Kementerian Agama Daerah Istimewa Yogyakarta", Jurnal Informatika, Maret, 2014.

KBBI, Kamus Besar Bahasa Indonesia, (Jakarta: Balai Pustaka, 2005).

Kementerian Agama, Realita Haji, (Jakarta: Kementerian Agama, 2014).

Kristanto, Andri, Perancangan Sistem Informasi dan Aplikasinya, (Yogyakarta: Gava Media, 2007).

Siagian, Sondang P, Sistem Informasi Manajemen, (Jakarta: Bumi Aksara, 2002).

Sutabri, Tata, Sistem Informasi Manajemen, (Yogyakarta: Andi, 2005).

Tulus, "Refleksi Perjalanan SISKOHAT”, Realita Haji, Edisi 02 Mei 2014.

Wawancara dengan Kepala Seksi Informasi Haji Kantor Wilayah Kementerian Agama Provinsi Jawa Tengah, 18-6-2015.

Wawancara dengan Kepala Seksi Informasi Haji Kantor Wilayah Kementerian Agama Provinsi Jawa Tengah, 18-6-2015.

Wawancara dengan Tim SISKOHAT Kantor Wilayah Kementerian Agama Provinsi Jawa Tengah, 30-6-2015. 